\title{
Al-Quran dalam Sejarah (Diskursus Seputar Sejarah Penafsiran al-Qur'an)
}

\author{
Abdul Rouf \\ Dosen UIN Syarif Hidayatullah Jakarta dan DPK Institut PTIQ Jakarta \\ HP 08159760464
}

\begin{abstract}
Abstrak: Secara normatif al-Qur'an diyakini memiliki kebenaran mutlak namun kebenaran penafsiran al-Qur'an bersifat relatif dan tentatif. Sebab tafsir adalah respons mufassir terhadap teks kitab suci, situasi dan problem sosial yang dihadapinya. Sehingga tidak ada penafsiran yang benar-benar objektif karena penafsiran terhadap suatu teks termasuk di dalamnya teks al-Qur'an sangatlah dipengaruhi oleh sejarah latar belakang keilmuan, kultur dan anggapan-anggapan yang melatarbelakngi penafsirnya. Sehingga kajian tentang sejarah penafsiran al-Qur'an memiliki daya tarik sendiri bagi mereka yang serius ingin memahami al-Qur'an. Karenanya tidak lah mengherankan jika di kalangan umat Islam selalu bermunculan produk-produk tafsir yang sarat dengan berbagai metode dan pendekatan penafsiran seiring dengan derap langkah perubahan dan tantangan zaman. Pada artikel ini penulis mendeskripsikan tentang sejarah penafsiran al-Qur'an melalui pembahasan tentang sejarah turunnya al-qur'an, sejarah penafsiran al-Quran mulai dari penafsiran dengan menggunakan riwayat, akal dan olah batin.
\end{abstract}

Kata Kunci: al-Quran, tafsir, problem penafsiran.

\section{A. Pendahuluan}

Al-Quran memberikan petunjuk dalam persoalan-persoalan akidah, syariah, dan akhlak dengan jalan meletakan dasar-dasar prinsipil mengenai persoalan-persoalan tersebut. Dan Allah menugaskan Rasul-Nya saw untuk 
memberikan keterangan yang lengkap mengenai dasar-dasar itu. ${ }^{1}$ Al-Qur'an ${ }^{2}$ Meskipun kitab-kitab yang diturunkan kepada para Nabi terdahulu, terutama kitab-kitab suci orang Nasrani dan Yahudi dipandang suci oleh orang-orang Islam, namun, al-Qur'an yang diwahyukan kepada Nabi Muhammad saw adalah kitab suci paling utama. Sementara ajaran yang ditunjukkan oleh al-Qur'an bukanlah sesuatu yang baru, melainkan serupa doktrinnya dengan kitab-kitab suci para Rasul-Nya yang terdahulu. ${ }^{3}$ Dalam rangka itu, al-Qur'an meletakkan dasar keyakinan yang sama dengan yang dianut oleh Nabi Nuh dan Ibrahim. ${ }^{4}$

Al-Qur'an adalah kitab petunjuk yang di dalamnya memuat ajaran moral universal bagi umat manusia sepanjang masa. Dalam posisinya sebagai kitab petunjuk, al-Qur'an diyakini tidak akan pernah lekang dan tertinggal oleh zaman. Akan tetapi dalam kenyataannya, teks al-Qur'an sering kali dipahami secara parsial dan ideologis sehingga menyebabkannya seolah menjadi teks yang mati dan tak lagi relevan dengan perkembangan zaman. Fenomena inilah yang menggelisahkan para mufassir (ahli tafsir) modern-kontemporer dan berusaha melakukan re-interpretasi agar kitab suci umat Islam ini benar-benar menjadi kitab petunjuk yang akan senantiasa relevan untuk setiap zaman dan tempat serta mampu merespons setiap problem sosial-keagamaan yang dihadapi oleh umat manusia. Ini mengindikasikan bahwa pemahaman terhadap al-Qur'an harus di geser dan diubah dari paradigma literalis-ideologis yang sudah berlangsung selama beberapa abad lamanya menjadi paradigma kritis-kontekstual. Tanpa adanya perubahan paradigma dalam membaca dan memahami kalam Tuhan tersebut maka yang muncul hanyalah pembacaan yang berulang-ulang (qira'ah mutakarrirah) dan tidak produktif.

Agar benar dalam berakidah dan pesan-pesan moral yang ada dalam al-Qur'an dapat dipahami secara benar dan dilaksanakan secara tepat, maka pemeluknya harus mempelajari prinsip-prinsip dasar dalam memahami al-Qur’an.

\footnotetext{
${ }^{1}$ Sebagaimana penjelasan Allah pada QS. Al-Nahl[16] 44.

${ }^{2}$ Kata al-Qur’an berasal dari kata kerja qara’a yang berarti mengumpulkan atau menghimpun, dan juga membaca atau mengaji. Al-Qur'an itu memang merupakan himpunan ajaran agama terbaik yang harus dibaca dan dikaji. Nama-nama Al-Qur'an lainnya, antara lain: a. al-Furqan: yang membedakan (antara yang benar dan yang salah, antara yang baik dan yang buruk, dan seterusnya); b. al-Haqq: kebenaran Ilahi yang mutlak sempurna; c. al-Hikmah: hikmah atau kebijaksanaan; d. al-Huda: petunjuk hidup; e. al-Shifa: penyembuhan ruhani; f. al-Dzikr: pengingat. Lihat Endang Saifuddin Anshari, Wawasan Islam Pokok-pokok Pikiran tentang Islam dan Ummatnya (Bandung: Pustaka,1983), hal. 31.

${ }^{3}$ QS, Al-Ahqaf [46] 9-10.

${ }^{4} \mathrm{QS}$, Al-Shura [42] 13.
} 


\section{Tujuan Pokok Turunnya Al-Qur'an}

Islam datang ke dunia ini untuk mewujudkan kemaslahatan umat manusia dan melepaskan penderitaan mereka. Ia datang sebagai respons terutama atas kesengsaraan hidup dan ketidak adilan yang terjadi di tengah-tengah umat manusia. Dalam konteks penderitaan umat manusia, agama menyuguhkan ajaran cinta-kasih sebagai pondasi untuk melawan kegetiran dan penderitaan hidup dimaksud. Ajaran dan dogma cinta kasih merupakan simpati Islam untuk membebaskan mereka yang tertindas. Pembebasan demi untuk mensejatrakan umat manusia adalah misi utama Islam. Islam datang untuk membela kelompok lemah (al-mustad'afin).

Islam datang demi untuk tegaknya keadilan dan kesejahtraan dunia baru kemudian disusul dengan keadilam dan kesejahtraan akhirat. Allah menegaskan, keadilan merupakan ukuran kualitas ketakwaan seseorang. Disebutkan dalam al-Qur'an pada QS Ali Imran ayat 8

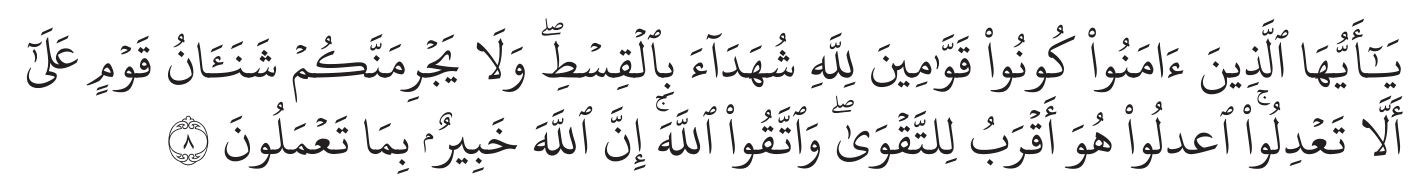

Hai orang-orang yang beriman hendaklah kamu jadi orang-orang yang selalu menegakkan (kebenaran) karena Allah, menjadi saksi dengan adil. Dan janganlah sekali-kali kebencianmu terhadap sesuatu kaum, mendorong kamu untuk berlaku tidak adil. Berlaku adillah, karena adil itu lebih dekat kepada takwa. Dan bertakwalah kepada Allah, sesungguhnya Allah Maha Mengetahui apa yang kamu kerjakan. (QS Ali 'Imran [5] 8)

Oleh karena itu, arti takwa di dalam Islam tak berhenti pada menjalankan ibadah ritual. Ketakwaan akan lebih bermakna jika disertai keadilan sosial. Keadilan tidak akan tercipta tanpa membebaskan masyarakat lemah. Fahmi Huwaidi mengutip pernyataan al-Shatibi, keadilan dan kesejatraan merupakan tujuan puncak (al-ghayah al-maqsudah) syariat Islam. ${ }^{5}$

Al-Quran meminta agar umat Islam menjadi pembela kelompok tertindas dan golongan lemah. ${ }^{6}$ Sepanjang hidupnya, Rasulullah berpihak kepada kelompok-kelompok lemah dalam menghadapi kelompok-kelompok kuat. Pemihakan kelas dalam Islam bertujuan menegakkan keadilan. Pemihakan ke-

${ }^{5}$ Fahmi Huwaidi, Al-Qur'an wa Al-Sultan: Humum Islamiyah Mu'ashirah (Kairo: Dar alShuruq, 1998), hal.157-159

${ }^{6}$ QS. Al-Nisa'[4] 75. 
las dapat terjadi di dalam semua sitem sosial, karena kelompok al-mustad'afin (orang-orang yang lemah) ada di dalam seluruh sitem kemasyarakatan.

Menurut al-Qur'an, orang yang tidak menyantuni kelompok duafa atau al-mustad'afin disebut sebagai orang yang mendustakan agama. ${ }^{7}$ Sebagai bukti pemihakan Islam terhadap kelompok lemah dan miskin adanya ketetapan zakat yang harus dikeluarkan oleh orang-orang kaya. Zakat merupakan kewajiban yang harus dilaksanakan orang kaya, karena itu kaum miskin boleh menuntunya jika orang kaya tidak mengeluarkannya dan negara dapat memaksanya. ${ }^{8}$

Zakat seperti digariskan al-Qur'an bertujuan mendistribusikan kekayaan dan karunia Allah secara adil. ${ }^{9}$ Sejarah menunjukan kehadiran Islam merupakan revolusi yang berperan secara signifikan dalam sejarah kehidupan umat manusia. Islam telah menjadi penanda perubahan, bukan hanya dalam tataran teologi melainkan juga dalam sosial dan ekonomi. Tujuan dasarnya adalah persaudaraan universal, kesetaraan, dan keadilan sosial.

\section{B. Sejarah Turunnya Al-Qur'an (Mengenal Ilmu Asbab Al- Nuzul)}

Al-Qur'an terdiri 114 surat, dengan surat terpanjang terdiri atas 286 ayat, yaitu Al Baqarah, dan terpendek terdiri dari 3 ayat, yaitu Al-'Asr, Al-Kauthar, dan Al-Nashr. Sebagian ulama menyatakan jumlah ayat dalam al-Qur'an adalah 6.236, sebagian lagi menyatakan 6.666. Perbedaan jumlah ayat ini disebabkan karena perbedaan pandangan tentang kalimat Basmalah pada setiap awal surat (kecuali al-Taubah). Kemudian tentang kata-kata pembuka surat yang terdiri dari susunan huruf-huruf seperti Ya Sin, Alif Lam Mim, Ha Mim dll. Ada yang memasukkannya sebagai ayat, ada yang tidak mengikut sertakannya sebagai ayat.

Untuk memudahkan pembacaan dan penghafalan, para ulama membagi Al-Qur'an dalam 30 juz yang sama panjang, dan dalam 60 hizb (biasanya ditulis di bagian pinggir al-Qur'an). Masing-masing hizb dibagi lagi menjadi empat dengan tanda-tanda al-rub' (seperempat), al-nisf (seperdua), dan al-sulus (tiga perempat).

Selanjutnya al-Qur'an dibagi pula dalam 554 ruku', yaitu bagian yang terdiri atas beberapa ayat. Setiap satu ruku' ditandai dengan huruf 'ain di sebelah pinggirnya. Surat yang panjang berisi beberapa ruku'. Sedang surat yang pendek hanya berisi satu ruku'. Nisf al-Qur'an (tanda pertengahan al-Qur'an), terdapat

${ }^{7}$ QS. Al-Maun [107] 1-5.

${ }^{8}$ QS. Al-Hashr [59] 7.

${ }^{9}$ QS. Al-Taubah [7] 103. 
pada surat al-Kahfi ayat 19 pada lafal walyatallataf yang artinya: "hendaklah ia berlaku lemah lembut".

Untuk memahami al-Qur'an secara benar dan tepat, sejarah ${ }^{10}$ turunnya al-Qur'an (Ilmu asbab al-nuzul) sebagai suatu keniscayaan yang mesti diketahui oleh setiap orang yang ingin mengkaji al-Qur'an.

Al-Qur'an diturunkan dalam dua periode. Pertama; periode Mekah, yaitu saat Nabi saw bermukim di Mekah (610-622 M) sampai Nabi SAW melakukan hijrah. Ayat-ayat yang diturunkan pada masa itu disebut ayat-ayat Makkiyah, yang berjumlah 4.726 ayat, meliputi 89 surat. Kedua; adalah Periode Madinah, yaitu masa setelah Nabi saw hijrah ke Madinah (622-632 M). Ayat-ayat yang turun dalam periode ini dinamakan ayat-ayat Madaniyyah, meliputi 1.510 ayat dan mencakup 25 surat.

Dengan membagi sejarah turunnya al-Qur'an menjadi dua periode, hal itu memudahkan bagi para pengkaji al-Qur'an untuk memahami petunjuk alQur'an secara utuh dan tujuan-tujuan pokok dalam al-Qur'an. Karena tujuan utama mempelajari ilmu asbab al-nuzul adalah bagaimana mestinya al-Qur'an itu dipahami secara proporsional dan benar.

Sebagai contoh bagaimana memahami terminologi dan perintah jihad dalam perspektif ilmu asbab al-nuzul?. Dan bagaimana sesungguhnnya mengetahui sejarah turunnya ayat al-Qur'an (asbab al-nuzul) ayat sangat membantu dalam memahami ayat al-Qur'an.

Secara etimologis, kata jihad merupakan kosa kata Arab yang sudah diserap ke dalam bahasa Indonesia. Asal katanya adalah juhd atau jahd. Yang pertama diartikan sebagai mengeluarkan tenaga, usaha, atau kekuatan. Sedang yang kedua maknanya adalah kesungguhan dalam bekerja. ${ }^{11}$ Dengan demikian, secara bahasa jihad adalah mengerahkan tenaga dan kemampuan untuk melakukan sesuatu dengan penuh kesungguhnan.

Selain itu kata jihad juga berarti perang. Tetapi untuk pengertian perang ini, al-Qur'an juga mempergunakan dua kata lainnya yaitu al-qital dan al-harb.

Perintah jihad dalam al-Qur'an bermula sejak Nabi Muhammad berdakwah di Mekkah. Namun pemakaian kata jihad tidak bermakna perang dan

\footnotetext{
${ }^{10}$ Menurut Sartono Kartodirdjo, sejarah adalah usaha dan perbuatan deskripsi tentang masa lampau dengan merekonstruksikan "apa yang terjadi” dan diuraikan sebagai cerita. Dengan kata lain, kejadian-kejadian penting yang diseleksi dan diatur menurut proses waktu sedemikian sehingga tersusun sebagai cerita atau story. Lihat Sartono Kartodirdjo, Pemikiran dan Perkembangan Historiografi Indonesia, Suatu Alternatif (Gramedia, Jakarta, 1984), hal. 5.

${ }^{11}$ Ibn Manzur Muhammad ibn Makram, Lisan al-Arab , (Baerut: Dâr Al-Fikr, 1994), vol iii, hal. 133-134.
} 
perlawanan fisik. Jihad dipakai dalam makna perjuangan yang substantif, etis, moral, dan spiritual. Allah swt. Berfirman pada Surat Al-Furqan 52.

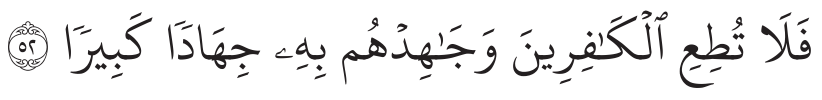

"Maka janganlah kamu mengikuti orang-orang kafir, dan berjihadlah terhadap mereka dengan jihad yang besar." (QS al-Furqan [25] 52)

Terkait dengan ayat di atas, para ahli tafsir berbeda pendapat mengenai dengan apa berjihad? Menurut Ibnu Abbas as., konotasi makna jihad dalam ayat itu adalah dengan 'al-Quran'. Menurut Ibnu Zayd dengan 'Islam'. Ada juga yang berpendapat dengan 'pedang'. Namun al-Qurtubi menolak keras pendapat yang terakhir (jihad dengan pedang), karena ayat ini turun di Mekah sebelum ada perintah perang. ${ }^{12}$ Sedangkan makna jihad menurut al-Zamakhshari mencakup segala bentuk perjuangan (jamiun likulli mujahadah). ${ }^{13}$

Dalam ayat lain, Allah berfirman.

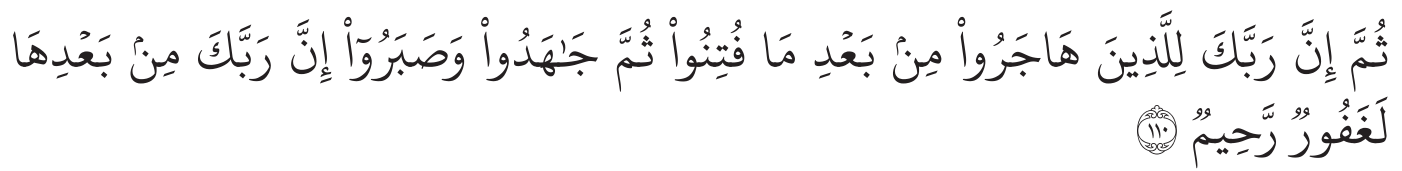

Dan sesungguhnya Tuhanmu (pelindung) bagi orang-orang yang berhijrah sesudah menderita cobaan, kemudian mereka berjihad dan sabar; sesungguhnya Tuhanmu sesudah itu benar-benar Maha Pengampun lagi Maha Penyayang (QS al-Nahl [16] 110).

Ada sebagian ulama tafsir-di antaranya al-Dahhak-meragukan keberadaan ayat-ayat jihad turun di Mekah, termasuk dua ayat di atas. Mereka berpendapat ayat-ayat tersebut turun di Madinah. Pasalnya, jihad identik dengan makna perang, sedangkan dalam periode Mekah tidak pernah terjadi peperangan. Apalagi disebutkan dalam ayat kedua (Al-Nahl/16:110), "Orang-orang yang berhijrah" (li al-ladzîna ha jarû) menjadi bukti bahwa perintah jihad hanya ada pada periode pasca hijrah ke Madinah. Disimpulkan ayat-ayat yang berbicara seputar jihad adalah ayat-ayat madaniyah bukan ayat-ayat makkiyah.

Tetapi mayoritas ulama berpendapat sebaliknya. Ayat jihad di atas turun di Mekah. Menurut mayoritas ulama, seluruhnya dalam surat al-Furqan turun

\footnotetext{
${ }^{12}$ Muhammad Ibn Ahmad al-Ansari al-Qurtubi, Al-Jâmi Li Ahkâm Al-Qur'an,( Baerut: Dâr Al-Fikr, 1995), vol vii, .hal. 56,

${ }^{13}$ Mahmud Ibn Umar al-Zamakhshari, Tafsir Al-Kashshaf, (Baerut: Dar Al-Kutub Al-'Ilmiyah, 1995), vol iii, hal. 278.
} 
di Mekah. Ibnu Abbas dan Qatadah memberi pengecualian tiga ayat dari surat al-Furqan turun di Madinah, yaitu ayat 68,69, dan $70 .^{14}$

Pendapat mayoritas ulama tersebut diperkuat dengan keberadaan ayat-ayat jihad lain yang turun di Mekah. Dan ayat-ayat tersebut tidak dalam makna perang, tetapi dalam makna dasar jihad yaitu kesungguhan dan kesusahan dalam mengeluarkan kekuatan dan kemampuan. Allah berfirman;

"Jika (kedua orang tuamu) 'berjihad' (memaksa) terhadapmu untuk menyekutukan Aku (Allah) sedangkan kamu tidak memiliki pengatahuan tentang itu, maka janganlah kamu mengikuti keduanya, tapi pergaulilah kedunya di dunia dengan baik." 15

Makna 'jihad' dari ayat di atas adalah kesungguhan dan keseriusan orang tua dengan mengeluarkan seluruh kemampuan mereka untuk mengajak anaknya menyekutukan Allah. Kemudian reaksi perjuangan /jihad anak terhadap orang tuanya adalah bersabar dan menahan diri untuk tidak mengikuti kemauan mereka, tetapi tetap memperlakukan keduan orang tuanya dengan baik.

Dalam ayat lain disebutkan tentang keberadaan jihad di Mekah, "Dan orang-orang yang berjihad untuk mencari (keridoan) Kami, benar-benar akan Kami tunjukan kepada mereka jalan-jalan Kami."16

Makna jihad dalam ayat ini, sesuai dengan kondisi sosial umat Islam ketika itu di Mekah adalah berjuang (berjihad) di jalan Allah dengan penuh kesabaran, menanggung penderitaan akibat cacian dan siksaan kamum Quraish.

Dengan perjuangan mereka, Allah akan memberi jalan keluar yang baik dan petunjuk -Nya. Menurut al-Zamakhshari, ayat ini tidak memiliki spesifikasi objek perjuangan (jihad). Hikmahnya, jihad (perjuangan) memiliki cakupan yang luas, baik jihad terhadap dorongan jiwa yang tercela, setan, ataupun, musuh agama. ${ }^{17}$ Namun setelah Nabi Muhammad hijrah ke Yathrib (Madinah), kondisi dan posisi sosial umat Islam berubah. Di Mekah, kondisi mereka sedikit, lemah, serta dalam posisi marjinal dan tertindas. Di Madinah, umat Islam berhasil menggalang kekuatan, dan membentuk struktur sosial yang kuat. Umat Islam tidak lagi menjadi kelompok atau komunitas kecil, tetapi telah menjadi sistem masyarakat yang sesungguhnya.

\footnotetext{
${ }^{14}$ Al-Zamakhshari, Tafsir Al-Kasysyaf, hal. 3.

${ }^{15}$ QS. Luqman [31] 15.

${ }^{16}$ QS Al-Ankabut [29] 69.

${ }^{17}$ al-Zamakhshari, Tafsir Al-Kasysyaf. vol iii, hal, 453.
} 
Dalam kondisi dan posisi ini, teror dan agresi militer kaum Quraish terus bergulir, malah semakin meningkat dan membabi buta. Tidak dielakkan, umat Islam harus mempertahankan eksistensi mereka dengan cara menyusun kekuatan militer untuk menghadapi ancaman dan agresi militer kaum Quraish. Dan mulai dari sini kata jihad berubah dan bergeser artinya menjadi perang.

Karenanya, kata jihad dalam arti perang barulah digunakan al-Qur'an pada ayat-ayat Madaniyah, setelah Nabi tinggal di Madinah. Karena izin berperang di jalan Allah memang barulah muncul pada masa tahun pertama hijrah sebagimana termuat dalam surat al-Hajj [22] 39-40. Allah swt. Berfirman;

"Telah diizinkan (berperang) bagi orang-orang yang diperangi, Karena Sesungguhnya mereka Telah dianiaya. dan Sesungguhnya Allah, benarbenar Maha Kuasa menolong mereka itu."18" (Yaitu) orang-orang yang Telah diusir dari kampung halaman mereka tanpa alasan yang benar, kecuali Karena mereka berkata: "Tuhan kami hanyalah Allah". dan sekiranya Allah tiada menolak (keganasan) sebagian manusia dengan sebagian yang lain, tentulah telah dirobohkan biara-biara Nasrani, gereja-gereja, rumah-rumah ibadat orang Yahudi dan masjid-masjid, yang di dalamnya banyak disebut nama Allah. Sesungguhnya Allah pasti menolong orang yang menolong (agama)-Nya. Sesungguhnya Allah benar-benar Maha Kuat lagi Maha Perkasa."19

Jadi, semenjak di Madinah umat Islam tidak serta merta diperintahkan berjuang dalam arti fisik (sekalipun sudah diizinkan berperang). Selama dua tahun mereka diperintahkan untuk berjuang dalam membangun struktur masyarakat dan menjalin kerjasama yang kuat dengan kabilah dan agama lain yang hidup di Madinah. Perjanjian tersebut dikenal dengan "Piagam Madinah" (Al-Wathîqah Al-Madaniyah).

Adapun perintah berperang secara fisik (bukan sekedar izin berperang) barulah turun pada tahun kedua hijriyah sebagaimana firman Allah swt. Dalam surat al-Baqarah/2: 193 dan 216:

"Dan perangilah mereka itu, sehingga tidak ada fitnah lagi dan (sehingga) ketaatan itu Hanya semata-mata untuk Allah. jika mereka berhenti (dari memusuhi kamu), Maka tidak ada permusuhan (lagi), kecuali terhadap orang-orang yang zalim." "Diwajibkan atas kamu berperang, padahal berperang itu adalah sesuatu yang kamu benci. boleh jadi kamu memben-

${ }^{18}$ QS. Al-Hajj [22] 39.

${ }^{19} \mathrm{QS}$. Al-Hajj [22] 40.

${ }^{20} \mathrm{QS}$. Al-Baqarah [2] 193. 
ci sesuatu, padahal ia amat baik bagimu, dan boleh jadi (pula) kamu menyukai sesuatu, padahal ia amat buruk bagimu; Allah mengetahui, sedang kamu tidak Mengetahui". ${ }^{21}$

Tetapi meskipun demikian, setelah turunnya perintah itupun, kata jihad masih diberikan makna lainnya selain perang yaitu berusaha sungguh-sungguh, bersabar dalam menanggung masalah hidup dan menanggung penderitaan akibat cacian dan siksaan kamum Quraish.

Berdasarkan pemaparan di atas, mesti dibedakan antara ayat-ayat jihad dan ayat-ayat perang (qitâl). Membedakan dua terminologi ini sangat urgen, karena pencampur adukan antara keduanya merupakan sebab utama kesalahan umat Islam memahami doktrin jihad. Sehingga tidak heran kalau jihad diidentikan dengan peperangan. ${ }^{22}$

Ayat-ayat al-Qur'an dan Hadis Nabi yang berkaitan dengan perang, harus diposisikan pada situasi perang dan digunakan hanya untuk menghadapi orang-orang yang memerangi Islam. Sementara ayat-ayat al-Qur'an dan Hadis Nabi yang berkaitan dengan situasi damai, mesti diposisikan pada situasi damai. Begitu juga sebaliknya. Membalik penerapan tersebut yaitu menggunakan ayat-ayat al-Qur'an dan Hadis Nabi yang berkaitan dengan perang untuk situasi damai dan atau menerapkan ayat-ayat al-Qur'an dan Hadis Nabi yang berkaitan dengan damai untuk situasi perang, hal itu sama halnya dengan memutar balikan dan mengacaukan ajaran Islam.

Beberapa Hadis yang mengindikasikan adanya arti jihad tidak selalu identik dengan perang yaitu Hadis yang diriwayatkan oleh Ahmad, Nasai dan dishahihkan oleh Al-Hâkim, "Berihadlah terhadap orang-orang musyrik dengan harta, jiwa, dan lidah kalian". ${ }^{23}$ Dalam riwayat lain disebutkan; "Ibadah haji dan umrah merupakan jihad yang tanpa harus ada peperangan." " ${ }^{4}$. Rasulullah juga bersabda; "berbakti kepada orang tua merupakan jihad." Manusia paling utama adalah orang mukmin yang berjihad di jalan Allah dengan jiwa dan hartanya." ${ }^{25}$ Dalam hadis yang diriwayatkan Al-Dailami dari Abu Dzar Al-Ghifari, Rasulullah bersabda; "Sebaik-baik jihad adalah berjuang melawan hawa nafsu karena Allah"

${ }^{21}$ QS. Al-Baqarah [2] 216.

${ }^{22}$ Jamal Al-Banna, Al-Jihad, (Kairo: Dâr Al-Fikr Al-Islâmi, 2002), hal, 5

${ }^{23}$ Muhammad bin Ismaill Al-Kahlanî, Subul Al-Salâm. (Bandung : Dahlan t.tp), vol. ii.

${ }^{24}$ HR. Ibnu Majah

${ }^{25}$ Ahmad Ibn Ali ibn Hajar Al-Atsqalânî, Fath Al-Bari bi Syarh Shahih Al-Bukhari. (Berut: Dar al-Fikr 2000). Hadis no. 2786 vol. iv, hal. 81. 
Dengan demikian, beberapa Hadis di atas menunjukkan adanya variasi bentuk jihad yang diakui dalam Islam sesuai dengan sabda Nabi. Jihad tidak selalu identik dengan peperangan dan pertempuran, tetapi makna jihad berubah bentuk sesuai dengan situasi dan kondisinya. Menurut sabda Nabi yang popular, jihad dalam bentuk peperangan adalah jihad terkecil (al-jihâd al-Ashghar), sedangkan jihad menghadapi diri sendiri adalah jihad terbesar (al-Jihâd al-Akbar).

Berdasarkan pemaparan di atas, bisa disimpulkan bagaimana arti jihad bisa berubah tergantung situasi dan kondisinya. Ayat-ayat al-Qur'an yang menggunakan kata jihad (ayat-ayat jihad) telah jelas makna dan tujuannya. Tidak mengalami penyempitan makna dalam arti perang seperti yang dipahami sebagian orang selama ini. Jihad dapat diartikan seluas-luasnya, sesuai dengan konteks sosial dan kemampuan yang dihadapi dan dimiliki umat Islam. Kesesuaian antara makna jihad dengan konteks sosial bukan berarti proses penyempitan tetapi merupakan proses kontekstualisasi ajaran Islam.

\section{Relasi Al-Qur'an dengan Kitab-Kitab Terdahulu}

Untuk menunjukan bagaimana relasi syariat Islam (al-Qur'an) dengan syariat (kitab-kitab) sebelumnya, menarik kalau membaca komentar Thabathaba’i dalam Tafsir-nya. Ia mengatakan;

"Sesungguhnya shariat Nabi Muhammad saw merupakan kompilasi wasiat-wasiat Allah kepada Nabi Nuh, Ibrahim, Isa ditambah dengan apa yang diwahyukan kepada Nabi Muhammad. Seluruh shariat yang diturunkan Allah kepada para Nabi-Nya merupakan agama yang satu yang wajib ditegakkan dan tak ada perselisihan di dalamnya"26

Berdasarkan penjelasan di atas terlihat sekali relasi yang sangat signifikan antara al-Qur'an (shariat Muhammad) dengan shariat (kitab-kitab) para Nabi sebeleumnya. Namun demikian bukan berarti semua agama sama persis dan sebangun. Perbedaan antara Islam dan agama sebelumnya biasanya terletak pada mekanisme pelaksanaan ajaran. Tujuan shari'at bisa sama (maqasid al-shariah), tetapi bentuk shariat boleh jadi berbeda. Sebab secara generis shariat itu sendiri berarti jalan (al-sabil, al-tariq).

\footnotetext{
${ }^{26}$ Thabathaba'i, Al-Mizan fi Tafsir al-Qur'an, , (Baerut: Dar al-Fikr t.tp.), vol xviii, hal, .2829. Hal yang senada dikemukakan al-Razi dalam tafsirnya "Sebagaian kelompok berkata; sesungguhnya Nabi Muhammad datang untuk menegakkan shariat Nabi Ibrahim. Nabi Muhammad hadir tidak membawa shariat tersendiri. Ia justru diutus untuk menghidupkan shariat Nabi Ibrahim. Pandangan didasarkan pada sebuah ayat, 'Hendaklah kamu (Muhammad) mengikuti agama Nabi Ibrahim'. Lihat. Fakhr al-Din al-Razi, Mafatih al-Ghaib, (Baerut: Dar al-Fikr, 1993), vol v, hal, 358.
} 
Sejarah menunjukan, umat sebelum Islam sudah melaksanakan salat, hanya saja jumlahnya berbeda dengan yang diwajibkan kepada umat Muhammad saw. Shata al-Dimyati menjelaskan; "Salat subuh dilaksanakan Nabi Adam, salat zuhur dilaksanakan Nabi Dawud, salat ashar dilaksanakan Nabi Sulaiman, salat maghrib oleh Nabi Ya'kub dan salat Isya oleh Nabi Yunus. ${ }^{27}$

Ada pendapat lain bahwa salat subuh untuk Nabi Adam, salat zuhur untuk Nabi Ibrahim, salat ashar untuk Nabi Sulaiman, dan salat maghrib untuk Nabi Isa. Sementara Ibn Qasim yang dikutip Syibramulisi yang dikutip lagi $\mathrm{Mu}-$ hammad Nawai al-Jawi, salat Isya memang kewajiban tambahan yang dikhususkan untuk Nabi Muhammad. ${ }^{28}$ Ibn Ishaq menceritakan, Nabi Ibrahim biasa menjalankan salat zuhur, ashar, maghrib, Isya dan fajar. ${ }^{29}$

Orang-orang Quraish Mekah melaksanakan salat dengan bertepuk tangan dan bernyanyi. Ini dilakukan karena mereka meyakini dengan cara itu akan mendapat rida Allah. Versi lain diajukan Ibnu Umar, bahwa mereka salat dengan tanpa gerak, meletakan dahi di atas tanah (bersujud). Ketika salah satu dari keluarga mereka meninggal dunia, keluarga yang hidup berdiri di atas kuburannya sambil menyebut kebaikan dari yang meninggal dunia itu. Mereka menyebut pekerjaannya ini sebagai salat. Sebelum matahari meninggi, Muhammad selalu melaksanakan salat dluha. Ia memberikan informasi tambahan, orangorang Majusi juga biasa melaksanakan salat 3 kali dalam sehari, waktu subuh, ashar, dan maghrib. ${ }^{30}$

Begitu juga dengan ajaran yang lain seperti puasa, ${ }^{31}$ zakat, sedekah, haji dan lain-lain juga dijelaskan oleh al-Qur'an.

\section{Diskursus Seputar Sejarah Penafsiran Al-Quran}

Al-Qur'an adalah teks keagamaan, kitab petunjuk seperti yang pernah dikatakan Abduh. Tetapi bagaimana kita bisa mencapai petunjuk itu? Bagaimana seharusnya kita memahami teks, agar petunjuk itu bisa diraih? Kita harus menafsirkannya. Al-Qur'an adalah pesan Tuhan yang memiliki kode dan saluran yakni berupa bahasa Arab. Untuk meretas kode yang digunakan diperlukan suatu analisis teks yang memiliki pesan-pesan etik dan moral spiritual.

\footnotetext{
${ }^{27}$ Muhammad Shata al-Dimyati, I'anah Talibin (Semarang: Thaha Putra, t.tp), vol i, hal. 21.

${ }^{28}$ Muhammad Nawawi al-Jawi, Nihayat al-Zain fi Irshad al-Mubtadi, (Semarang: Thaha Putra, t.tp.), hal,.8

${ }^{29}$ Ibn Ishaq, Al-Sirah Al-Nabawiyah (Kairo: Qutta al-Thaqafah, 1998), vol I, hal, 171.

${ }^{30}$ Jawwad Ali, Tarikh al-Salah fi Islam, (Baghdad: Matba'ah diya', t.tp.), hal, 10-18.

${ }^{31}$ Begitu juga dengan ajaran yang lain seperti puasa, zakat, sedekah, haji dan lain-lain juga dijelaskan oleh al Qur’an. Misalkan pada QS. Al-Baqarah [2] 183.
} 
Berdasarkan definisi ini maka segala upaya yang dimaksudkan memahami al-Qur'an dan menjelaskan firman Tuhan yang tertuang dalam teks alQur'an dapat disebut sebagai tafsir terlepas apakah penafsiran itu terpuji (mahmud) maupun tercela (madhmum).

Ketika kita berbicara tentang penafsiran maka problem utamanya adalah bagaimana memberi makna terhadap sebuah teks masa lalu yang kita baca. Apakah seorang mufassir hanya mengulang makna-makna masa lalu ketika teks itu muncul atau sebenarnya dia juga di beri hak dan bahkan dituntut untuk kreatif memproduksi makna-makna baru sesuai dengan tuntutan zaman. Sehingga penafsiran atau tafsir bisa diposisikan menjadi dua katagori penting; tafsir sebagai produk dan tafsir sebagai proses.

Tafsir sebagai produk adalah tafsir yang merupakan hasil penafsiran seorang mufassir dengan teks dan konteks yang melingkupinya yang tertuang dalam kitab-kitab tafsir baik secara lengkap (30 juz) maupun hanya sebagian ayat-ayat saja. Ia dipengaruhi oleh situasi dan kondisi sosio-historis, geo-politik bahkan juga oleh latar belakang keilmuan serta kepentingan mufassir-nya.

Sementara tafsir sebagai proses adalah aktifitas berfikir yang terus menerus dilakukan untuk mendialogakan teks al-Qur'an dengan realitas yang berkembang sehingga tetap eksis sepanjang zaman (Salih li kulli makan wa zaman). Dialog komunikatif antara teks al-Qur'an yang terbatas dengan realitas yag tidak terbatas (al-nusus mahdudah wa al-waqa'i ghair mahdudah) selalu dilakukan oleh mufassir sehingga tafsir merupakan sebuah proses yang tidak pernah selesai sampai kapanpun. Artinya tafsir dalam pengertian ini bersifat dinamis karena yang dimaksudkan untuk menghidupkan teks dalam konteks yang terus berkembang. Baik tafsir sebagai produk maupun tafsir sebagai proses telah banyak bermunculan dan terus dilakukan oleh para pengkaji al-Qur'an baik dari kalangan muslim maupun dari kalangan non-muslim.

Penafsiran atau Tafsir sebagai produk juga bisa dimaknai bahwa orientasi penafsirnya terjebak pada pengulangan pendapat-pendapat masa lalu yang belum tentu relevan dengan konteks kekinian. Bahkan akan mengalami kemandulan dalam memberi solusi terhadap problem sosial-keagamaan masyarakat kontemporer yang semakin kompleks. Akibatnya pemahaman yang muncul cenderung tekstualis dan literalis.

Sementara tafsir sebagai proses dapat dimaknai bahwa penafsir-nya dalam menjelaskan al-Qur'an selalu melihat konteks dan memperhatikan situasi sosio-historis masa lalu di saat teks itu turun untuk kemudian ditarik lagi ke dalam situasi saat ini. Penafsiran mereka terhadap ayat-ayat- al-Qur'an cenderung 
kontekstualis dalam arti selalu berupaya mengkontekstualisasikan makna ayat tertentu dengan mengambil prinsi-prinsip dan ide universalnya.

Berdasarkan pemaparan di atas, perjalanan penafsiran al-Qur'an secara koseptual bisa dipetakan sejarahnya secara jelas sebagai berikut:

\section{Sejarah Penafsiran Al-Qura'n dengan Menggunakan Riwayat (al- Tafsir bi al-Ma'thur)}

Pada masa ini yang dikenal masa awal (masa Rasul, sahabat dan tabi'in) mereka dalam menafsirkan al-Qur'an lebih berorientasi pada psesoalan bagaimana menentukan ragam qira'at yang terjadi masa itu. Hal ini dilakukan agar qira'at tersebut benar-benar valid dari Rasul saw sebab hal ini menyangkut otentisitas sebuah kitab suci dimana perbedaan qira'at terkadang dapat mempengaruhi penafsiran al-Qur'an sendiri. Hingg awal abad II H., tafsir lebih berorientasi pada periwayatan sehingga upaya memahami al-Qur'an dengan menggunakan ra'yu (akal) cenderung dibenci dan dijauhi. Dengan kata, yang disebut sebagai tafsir ketika itu hanyalah penjelasan atau interpretasi yang diberikan Rasul atas ayat-ayat al-Qur'an atau oleh para sahabat yang mendapat pengajaran tafsir dari Rasul yang kemudian di kenal dengan istilah al-tafsir bi al-ma'thur atau al-tafsir bi al-riwayah. Al-Tafsir bi al-Manthur, yaitu suatu usaha untuk menjelaskan isi kandungan al-Quran dengan ayat-ayat al-Quran itu sendiri atau dengan penjelasan Nabi atau penjelasan para sahabat dan tabi'in. ${ }^{32}$ Tafsir jenis ini disebut pula dengan tafsir bi al-riwayah. Tafsir jenis ini disepakati oleh para mufassir sebagai tafsir yang paling tinggi nilainya dan tidak ada pertentangan dikalangan mereka tentang kesahihannya.

Metode yang dipakai adalah metode riwayat. Hal ini bisa dimaklumikaren ketika itu yang disebut dengan ilmu adalah periwayatan itu sendiri. Sedangkan tolak ukur kebenaran tafsir ketika itu ditentukan oleh ke-thiqah-an atau ke-muttasil-an sanad (mata mata rantai periwatan). Model dan bentuk penafsiran di masa ini ditandai dengan pertama, penggunaan simbol-simbol tokoh untuk mengatasi persoalan. Dalam konteks penafsiran, simbol tokoh seperti Nabi, para sahabat dan bahkan para tabi' in cenderung dijadikan sebagai rujukan utama dalam menafsirkan al-Qur'an. Standar kebenaran tafsir juga ditentukan oleh ketokohan orang-orang tersebut. Kedua; cenderung kurang kritis dalam menerima produk penafsiran. Dalam knoteks penafsiran, al-Qur'an di posiskan sebagai subjek, sedangkan realitas dan penafsirnya diposisikan sebagai objek. Dengan kata lain, posisi teks menjadi sangat sentral sehingga model berfikir deduktif

${ }^{32}$ Muhammad Husyan al-Dhahabi, Al-Tafsir wa Al-Mufassirun, (Kairo: t.p. 1979), vol i, hal. 152. 
(menggunakan nalar langit) lebih mengemuka dari pada model berfikir induktif (menggunakan naral bumi). Karenanya, tidak mengherankan jika pada periode ini yang dominan adalah model al-tafsir bi al-riwayah, sedangkan (al-tafsir bi alra'y) cenderung dihindari dan bahkan dicurigai.

Misalnya era sepeninggalan Nabi hingga awal abad kedua hijriah para sahabat enggan menafsirkan al-Qur'an dengan menggunakan akal pikiran karena yang disebut ilmu pada saat ituadalah periwayatan itu sendiri. Ini terlihat dari sikap sebagian sahabat yang membenci penafsiran dengan ra'yu (akal) semisal Ibn Umar yang tidak mau menafsirkan al-Qur'an. Demikian pula keenggana Abu Bakar ketika ditanya tentang makna suatu ayat yang tidak ada penjelasan dari Nabi. Saat itu Abu Bakar sempat menyatakan "Di bumji mana saya harus berpijak dan di kolong mana langit mana saya harus berteduh apabila saya berbicara tentang al-Qur'an dengan akalku atau berdasarkan sesuatu yang saya tidak mengetahuinya. ${ }^{33}$

Pada masa ini Nabi Muhammad saw, setiap kali ada ayat turun beliau biasanya membacakan dan menjelaskannya kepada para sahabat, terutama menyangkut ayat-ayat yang mushkil (sulit dimengerti maksudnya). ${ }^{34}$ Pada masa itu penafsiran Nabi bersifat global (ijmali) dan disampaikan secara oral karena peradaban Arab saat itu adalah peradaban lisan dan periwayatan, bukan periwayatan peradaban tulis dan penalaran. ${ }^{35}$ Nabi Muhammad juga belum merumuskan metodologi tafsir secara sistematis sehingga tradisi penafsiran ketika itu lebih bersifat praktis. Terkait dengan keterlibatan Rasul dalam proses penafsiran al-Qur'an, Ibn Khaldun dalam Muqaddimah-nya mengatakan;

"Rasulullah saw menjelaskan makna al-Qur'an secara umum, membedakan ayat-ayat yang nasikh dan mansukh, kemudian memberitahukan kepada para sahabat sehingga mereka memahami sebab-musabab turunnya ayat (asbab al-nuzul) dan situasi yang mendukungnya". ${ }^{36}$

Dengan berakhirnya masa sahabat, tradisi penafsiran dilanjutkan oleh generasi tabi'in dengan pola yang relatif sama. Hal yang membedakan antara tradisi penafsiran era sahabat dengan era tabi'in barangkali hanya pada persoalan sektarianisme. Pada era sahabat belum muncul sektarianisme aliran-aliran seca-

\footnotetext{
${ }^{33}$ Ignaz Goldziher, Madhahib al-Tafsir al-Islami, (Kairo: Maktabah al-Sunnah al-Muhammadiyah, 1955), hal.73-80

${ }^{34}$ Baca contohnya QS. Al-Nahl/66: 44 “Dan Kami turunkan kepadamu al-Qur'an agar kamu menerangkan kepada umat manusia apa yang telah diturunkan kepada mereka dan supaya mereka memikirkannya".

${ }^{35}$ Muhammad 'Abed al-Jabiri, Bunyah al-Aql al-Arabi; Dirasah Tahliliyyah Naqdiyyah li Nuzum al-Ma'rifah li Thaqafah al-Arabiyyah, (Baerut: al-Markaz al-Thaqafi al-'Arabi), hal, 14.

${ }^{36}$ Ibn Khaldun, Muqaddimah Ibn Khaldun (Baerut: Dar al-Fikr, t.t.), hal, 489.
} 
ra tajam. Sementara di era tabi'in sudah mulai muncul aliran-aliran tafsir berdasarkan kawasan. Itu disebabkan karena para mufassir dari kalangan tabi'in yang dahulu berguru kepada para sahabat kemudian menyebar ke beberapa daerah.

Paling tidak ada tiga aliran penafsiran di era tabi'in. Pertama; aliran Makkah, yang dipelopori oleh Sa'id bin Jubair (w.712/713 M), 'Ikrimah (w. 723 M.) dan Mujahid Ibn Jabr (w. 722 M.). Mereka berguru kepada sahabat Ibn 'Abbas. Kedua; aliran Madinah, yang dipelopori oleh Muhammad bin Ka’b (w. 735 M.), Zayd ibn Aslam al-Qurazhi (w. 735 M.) dan Abu 'Aliyah (w. 708 M.). Mereka berguru kepada sahabat Ubay bin Ka'b. Ketiga; aliran Irak di mana tokoh-tokohnya adalah 'Alqamah ibn Qays (w. 720 M.), 'Amir al-Sha'bi (w. 723 M.), Hasan al-Basri (w. 738 M.), dan Qatadah ibn Di’amah al-Sadusi (w. 735 M.). Mereka berguru kepada sahabat Abdullah Ibn Mas'ud. Sementara itu, ada pula ulama yang menambahkan satu aliran lagi dalam tafsir tabi' in yaitu aliran Basrah, yang juga banyak dipengaruhi oleh aliran Makah. Diantara tokohnya adalah Ibn Sirin, Jabir ibn Zayd al-Azdi dan Abu Sha'sha. ${ }^{37}$

Penafsiran aliran Makkah dan Madinah cenderung bercorak tradisionalis dalam arti lebih banyak menggunakan riwayat. Sedangkan aliran Irak cenderung bercorak rasional sehingga memunculkan model al-tafsir bi al-ra'y. Hal itu boleh jadi karena kondisi geografis Irak yang cukup jauh dari Madinah (sebagai pusat studi Hadis) sehingga mereka cenderung menggunakan ra'yu (ijtihad) ketika tidak ditemukan riwayat. Selain itu secara politis, tradisi penafsiran yang cenderung rasional itu mendapat dukungan dari Gubernur 'Ammar ibn Yasir yang diangkat oleh Khalifah 'Umar bin Khattab. Dia adalah seorang sahabat yang rasional. ${ }^{38}$

Tafsir di era Nabi dan sahabat dan permulaan masa tabi'in sering dikatagorikan sebagai tafsir periode pertama atau era qabla tadwin, yakni sebelum dikodifikasikannya kitab-kitab Hadis dan tafsir secara mandiri. Sedangkan tafsir periode kedua bermula dari masa kodifikasi Hadis secara resmi, yakni pada masa pemerintahan Umar bin Abdul Aziz (99-101 H.) dimana ketika itu tafsir masih digabung dengan Hadis atau dihimpun dalam satu bab seperti bab-bab hadis. Tafsir periode ketiga terjadi pada era pasca tabi' in atau lebih tepatnya generasi tabi' al-tabi'in. Di antara para tokohnya adalah Yazid al-Sulami (w. 117 H.), Sufyan ibn 'Uyainah (w. 198 H.) dan Shu'bah ibn 'Ubadah (w. 205 H.). Namun sayangnya, karya tafsir mereka tidak sampai ke tangan kita kecuali sekedar nukilan-nukilan. Barangkali hanya kitab Ma'ani al-Qur'an karya al-Farra (w. 207. H.) yang sampai kepada tangan kita. Pada masa inilah pembukuan tafsir dila-

${ }^{37}$ Lihat! Ibn 'Ali al-Khudri, Tafsir al-Tabi'in, vol i, hal, 422-466.

${ }^{38}$ Manna' Khalil al-Qattan, Mabahis fi 'Ulum al-Qur'an (Jedah: Dar al-'Ilm wa al-Iman t.t.) hal. 330-331. 
kukan secara khusus, yang menurut para sejarawan dimulai pada akhir masa Dinasti Umayah dan awal Dinasti Abbasiyah. ${ }^{39}$

\section{Sejarah Penafsiran dengan Menggunakan Akal (Al-Tafsir bi Al-Ra'y)}

Sejarah penafsiran kemudian berkembang dengan munculnya golongan ahl al-ra'y, yakni para pengikut muktazilah yang tidak puas dengan model tafsir riwayat (al-tafsir bi al-ma'thur). Era ini terjadi pada Abad Pertengahan ketika tradisi penafsiran Qur'an lebih didominasi kepentingan-kepentingan politik, mazhab, atau ideologi keilmuan tertentu sehingga al-Qur'an sering kali diperlakukan sekedar sebagai legitimasi bagi kepentingan-kepentingan tersebut. Para mufassir pada era ini pada umumnya sudah diselimuti "jaket ideologi" tertentu sebelum mereka menafsirkan al-Qur'an. Akibatnya, al-Qur'an cenderung 'diperkosa' menjadi objek kepentingan sesaat untuk membela kepentingan subjek (penafsir dan penguasa).

Al-Tafsir bi al-Ra'y, yaitu suatu usaha menafsirkan al-Qur'an berdasarkan atas hasil kajian (ijtihad) seorang mufassir sendiri dengan tetap berpegang kepada pengetahuan tentang bahasa Arab dan cabang-cabangnya. ${ }^{40}$ Tafsir jenis ini disebut dengan tafsir bi al-dirayah.

Mereka mulai menggunakan akal dalam menafsirkan ayat-ayat alQur'an terutama terhadap ayat-ayat mutashabbihat. Mereka bahkan melakukan perlawanan terhadap model penafsiran riwayat (al-tafsir bi al-ma'thur) yang dipandang tidak sejalan dengan akal. Karenanya, sejak saat itu apa yang disebut dengan tafsir tidak lagi hanya pemahaman atau penjelasan suatu maksud ayat al-Qur'an berdasarkan riwayat dari Nabi atau patra sahabat, tetapi tafsir juga adalah penafsiran yang didasarkan pada ra'yu atau ijtihad akal pada era ini mulai muncul bias-bias ideologi Muktazilah. Penafsiran mulai disesuaikan dengan mazhab ideologi mereka. Akhirnya kebenaran tafsir berdasarkan nalar ideologi yang dianutnya. Sejarah juga membuktikan bahwa bahwa pada waktu itu lahir aliran-aliran teologi seperti Ahlusunnah, Qadariyah, Syiah dan Khawarij dimana masing-masing aliran ini memiliki nalar epsitemik sendiri-sendiri dalam memhami al-Qur’an. Akibatnya, produk tafsir sedikit banyak juga dipengaruhi oleh bayang-bayang ideologi mereka. ${ }^{41}$ Tetapi sejalan dengan itu juga tradisi penafsiran terus berkembang. Hal ini terbukti dengan munculnya kitab-kitab tafsir yang sangat beragama. Bahkan sejak abad ketiga hingga sekitar abad keempat hijriah bidang tafsir menjadi disiplin ilmu yang mendapatkan perhatian khusus

${ }^{39}$ Al-Zakarshi. Al-Burhan fi Ulum al-Qur'an (Mesir: 'Isa al-Bab al-Halabi, 1972), vol i, hal, 159.

${ }^{40}$ Al-Zarqani, Manahil, vol.ii, hal, 255.

${ }^{41}$ Goldziher, Madhahib al-Tafsir, hal, 73-82. 
dari para sarjana muslim. Setiap generasi muslim dari masa ke masa telah melakukan interpretasidan re-interpretasi tehadap al-Qur'an.

Sampai pada akhirnya sampai kepada masa pembaharuan dalam Islam. Sejarah penafsiran al-Quran pada era ini berbasis pada nalar akal yang kritis dan bertujuan tranformatif. Era ini dimulai dengan tokoh-tokoh Islam seperti Sayyid Ahmad Khan dengan Tafhim Al-Qur'an Muhammad 'Abduh dengan Tafsir al-Manar-nya yang mengkritisi tafsir-tafsir ulama terdahulu yang dianggap tidak lagi relevan. Langkah Sayyid Ahmad Khan dan Muhammad Abduh ini kemudian dilanjutkan oleh para penafsir kontemporer seperti Fazlur Rahman, Muhammad Syahrur, Muhammad Arkoun, dan Hasan Hanafi. Para tokoh ini pada umumnya bersikap kritis terhadap produk penafsiran masa lalu yang selama ini banyak konsumsi oleh umat Islam. Mereka juga cenderung melepaskan diri dari model-model berpikir mazhabi. Sebagian dari mereka telah memanfaatkan perangkat keilmuan modern. Dengan beramgkat dari keprihatinan mereka terhadap produk tafsir masa lalu yang cenderung ideologis, sektarian, dan tak lagi mampu menjawab tantangan zaman, mereka kemudian coba membangun sebuah epsitimologi tafsir baru yang dipandang akan mampu merespons perubahan zaman dan kemajuan ilmu pengetahuan. Di era ini, posisi al-Qur'an, realitas, dan penafsir berjalan sirkular secara tradik dan dinamis. Untuk menjalankan semangtnya, penafsiran di era ini ada beberapa didasarkan pada beberapa asumsi yang digunakan dalam menafsirkan al-Qur'an. Diantara asumsi tersebut;

\section{a. Al-Qur'an salihun li kulli zaman wa makan (al-Qur'an itu kitab suci yang selalu eksis di setiap zaman dan tempat).}

Asumsi ini membawa implikasi bahwa problem-problem sosial keagamaan di era ini tetap akan dijawab oleh al-Qur'an dengan cara melakukan kontekstualisasi penafsiran secara terus menerus, seiring dengan semangat tuntutan problem zaman. Sebab al-Qur'an bukanlah kitab hanya diturunkan untuk orang-orang dizaman Nabi, tetapi ia juga diperuntukan bagi orang sekarang dan masa mendatang. Prinsip-prinsip universal al-Qur'an dijadikan pijakan untuk menjawab tuntutan perkembangan zaman yang bersifat temporer dan partikular.

\section{a. Al-Nusus Mahdudah wa al-Waqa'i Mutatawwirah (Teks itu terbatas sementara realitas terus berkembang).}

Kondisi ini meniscayakan para mufassir untuk selalu berusaha mengaktualkan dan mengkontekstualisasikan pesan-pesan universal al-Qur'an kedalam konteks partikular era kontemporer. Hal ini hanya dapat dilakukan jika 
al-Qur'an ditafsirkan sesuai dengan semangat zamannya berdasarkan nilai dan prinsi-prinsi dasar universal al-Qur'an.

Al-Qur'an yang diturunkan pada waktu tertentu dalam sejarah-dengan keadaan umum dan khusus yang menyertainya-seringkali menggunakan ungkapan-ungkapan yang sesuai dengan situasi yang mengelilinginya. Ayat-ayat tersebut tidak dapat direduksi atau dibatasi oleh situasi historis pada saat ia diwahyukan. Karenanya seorang mufassir senantiasa dituntut untuk mampu menagkap pesan moral yang ada dibalik teks yang bersifat literal. Dengan demikian, dalam rangka memelihara relevansi al-Qur'an dengan perkembangan zaman, maka ia harus terus-menerus ditafsirkan.

\section{c. Penafsiran Bersifat Relatif dan Tentatif}

Secara normatif al-Qur'an diyakini memiliki kebenaran mutlak namun kebenaran produksi penafsiran al-Qur'an bersifat relatif dan tentatif. Satu kaidah fikih mengatakan: "al-Ijtihad la yunqadu bi al-Ijtihad" (satu hasil Ijtihad seseorang ulama tidak bisa dibatalkan dengan ijtihad ulama yang lainnya". Kaidah ini menegaskan bahwa hasil penafsiran seseorang tidak lah mutlak sifatnya. Sebab tafsir adalah respons mufassir ketika memahami teks kitab suci, situasi dan problem sosial yang dihadapinya. Jadi, sesungguhnya ada jarak antara al-Qur'an dan penafsirnya. Sehingga tidak ada penafsiran yang benar-benar objektif karena penafsiran terhadap suatu teks termasuk di dalamnya teks al-Qur'an sangatlah dipengaruhi oleh latar belakang keilmuan, kultural dan anggapan-anggapan yang melatarbelakngi penafsirnya.

Dengan demikian, hasil penafsiran itu tidaklah sama dengan al-Qur'an itu sendiri. Karena sebuah penafsiran tidak hanya memproduksi makna teks, tetapi juga memproduksi makna baru teks. Sehingga ide-ide kreatif dan inovatif dalam menafsirkan al-Qur'an menjadi suatu keniscayaan. Berbagai kajian alQur'an secara intensif juga dilakukan di era ini. Fenomena tersebut memberikan isyarat betapa al-Qur'an memiliki daya tarik tersendiri, baik bagi mereka yang menkajinya sekedar untuk tuntutan akademis, maupun bagi mereka yang mengkajinya untuk mendapatkan petunjuk darinya. Karenanya tidak lah mengherankan jika di kalangan umat Islam selalu bermunculan produk-produk tafsir yang sarat dengan berbagai metode dan pendekatan seiring dengan derap langkah perubahan dan tantangan zaman.

\section{Sejarah Penafsiran Dengan Menggunakan Olah Batin (Al-Tafsir Al- Sufi)}

Dalam perkembangan berikutnya, muncul model penafsiran sufistik yang menggunakan nalar irfani. Asumsi dasar dari model tafsir ini adalah bahwa 
al-Qur'an meiliki makna lahir dan makna batin. Menurut kalangan sufi, menafsirkan al-Qur'an berdasarkan analisi kebahasaan saja tidaklah cukup dan dan hal itu dipandang baru memasukai tatanan makna lahir (eksoteris) saja, yang oleh para sufi dinilai sebagai tataran badan al-'aqidah. Sementara model tafsir sufi menempati posisi ruhnya (esoteris). Bagaimana mungkin tubuh itu akan hidup tanpa $\mathrm{ruh}^{42}$. Dari perjalanan sejarah tersebut, dapat dilihat bahwa hakikat tafsir telah mengalami pergeseran paradigma dan espitimologi dimana tafsir tidak hanya didasarkan pada riwayat dan akal, tetapi juga didasarkan pada ayat-ayat alQur'an yang berlandaskan isyarat-isyarat dan simbol melalui riyadah ruhaniyah (latihan ruhani) yang kemudian melahirkan pengalaman al-kashf sebagaimana dilakukan para sufi. Tafsir sufi intuitif atau simbolis (al-tafsir al-sufi al-ishari) yaitu takwil al-Quran yang berbeda dengan arti lahir ayat dimana pola pentafsirannya didasarkan kepada arti batin (isharah), yakni arti yang tersirat di balik yang tersurat. ${ }^{43}$

Al-Sabuni mendefinisikan al-tafsir al-sufi al-ishari, yaitu "Pentakwilan ayat-ayat al-Quran yang berbeda dengan arti zahirnya dikarenakan adanya isyarat-isyarat tersembunyi, hanya dilihat oleh sebahagian ulama (ulu al-'ilm). Atau orang-orang yang menempuh jalan ruhani dan berjihad melawan nafsu. Mereka adalah orang-orang yang diterangi penglihatan hatinya oleh Allah, sehingga mereka menemukan rahasia-rahasia al-Quran. Pengungkapan terhadap apa yang tertanam dalam hatinya dan sebagian makna-makna yang halus dengan perantaraan ilham Ilahi, dan dapat juga memadukan di antara keduanya (arti batin dan arti zahir ) dan apa yang dimaksud oleh ayat-ayat al-Qur'an”. ${ }^{44}$

Berdasarkan pemaparan di atas, secara garis besar penafsiran al-Quran dalam sejarah pemikiran Islam dapat dikategorikan menjadi dua pola. Pertama, penafsiran yang didasarkan pada kaedah bahasa Arab, itulah yang dikenali dengan pentafsiran lahir dan selalu dilakukan oleh kebanyakan para mufassir. Sementara pola kedua, pentafsiran yang didasarkan pada arti batin (isharah), yakni arti yang tersirat di balik yang tersurat, dengan merujuk antara lain kepada suatu Hadis yang menjelaskan tentang pentakwilan Ibn 'Abbas terhadap surah al-Nasr. Hadis yang dimaksudkan berbunyi:

"Ibn 'Abbas r.a. berkata, sesungguhnya Umar mengikut sertakan aku (dalam sebuah forum) bersama para veteran perang Badar. Sebagian mereka merasa keberatan (dengan keberadaan saya) seraya berkata "kenapa engkau mengikut sertakan anak ini bersama kami, padahal kami juga memiliki anak seperti dia? Kata 'Umar itulah menurut pengetahuan kamu (tentang dia). Suatu ketika, aku dipanggil oleh Umar bersama mereka dan

\footnotetext{
${ }^{42}$ Goldziher, Madhahib al-Tafsir, hal, 121-129 dan 286.

${ }^{43}$ Al-Dhahabi, Al-Tafsir, hal, 352.

${ }^{44}$ Ali A1-Sabuni, al-Tibyan fî 'Ulum al-Qur'an ( Baerut: 'Alam al-Kutub,t.t.), hal, 171.
} 
aku yakin bahwa beliau memanggil aku dengan tujuan ingin mendemontrasikan kebolehan aku di hadapan mereka. Umar berkata kepada mereka" bagaimana pendapat kamu tentang firman Allah S.W.T. (apabila datang pertolongan Allah dan (hari) kemenangan)? "Sebagian mereka menjawab: kami diperintahkan memuji Allah dan beristighfar apabila telah mendapat pertolongan dan kemenangan", sementara yang lain berdiam (tidak menjawab). Umar bertanya kepadaku "apakah demikian pula pendapatmu wahai Ibnu 'Abbas? Aku menjawab "tidak". Lalu Umar berkata: "bagaimana pendapatmu? Aku menjawab: "itu adalah ajal Rasulullah saw yang diberitahukan oleh Allah kepadanya. Allah berfirman (apabila telah datang pertolongan Allah dan (hari) kemenangan), itu adalah tanda ajalmu, (maka bertasbihlah dengan memuji Tuhanmu dan mohonlah ampunan kepada-Nya, sesungguhnya Dia Maha Penerima taubat). Umar berkata lagi: "saya tidak mengetahui (tentang penafsiran seperti itu) kecuali yang engkau katakan itu". (HR. Al-Bukhari). ${ }^{45}$

Apabila diteliti kandungan Hadis tersebut di atas, ternyata Ibn 'Abbas ra.-dalam usianya yang masih muda-dapat menangkap suatu pemahaman yang tersurat di balik arti lahir ayat-ayat surat al-nasr tersebut, dimana pemahamannya berbeda dengan apa yang dipahami oleh kebanyakan sahabat senior. Sekalipun pentafsiran Ibn 'Abbas tidak sama dengan hasil pentafsiran-pentafsiran yang dilakukan oleh para mufassir isharah, namun dapat membuka peluang bagi siapa saja yang mempunyai kemampuan untuk menemukan makna-makna atau isyarat-isyarat yang tersirat di balik yang tersurat.

Akan tetapi, oleh karena dalam tafsir sufi dinilai terdapat penyimpangan penafsiran, maka para ulama ahli syariat kemudian memberikan beberapa persyaratan. Al-Zarqânî menyebutkan paling tidak ada empat syarat: a). tidak bertentangan dengan lahir susunan al-Qur'an al-Karim. b). harus mempunyai shâhid syar'i (saksi hukum) yang mendukungnya c). tidak terjadi kontradiksi baik secara shar'i mapun secara 'aqli, d). tidak mengakui bahwa hasil pentafsiran secara isyarah itu satu-satunya yang dikehendaki, dengan mengabaikan arti lahir e). Pentakwilannya tidak terlalu jauh dari kebenaran. Apabila syarat-syarat ini dapat terpenuhi, maka tidak ada alasan untuk tidak menerimanya. Dengan catatan bahwa yang dimaksud menerima di sini ialah tidak menolaknya, bukan berarti wajib mengambil dan mempercayainya. ${ }^{46}$

${ }^{45}$ Abu 'Abdillah Muhammad Ibn Isma'il al-Bukhari, Al-Jami' al-Sahih Al-Mukhtasar, (Baerut: Dar Ibn Kathir, 1987), bab surah al-Nasr, nomor Hadis : 2179, j. 4. h.1901.

${ }^{46}$ Al-Zarqani, Manahil, hal, 88. 


\section{F. Kesimpulan}

Percaya kepada semua kitab suci yang diturunkan Allah termasuk rukun iman dalam Islam. Tidak bisa seseorang mendeklarasikan diri sebagai orang mukmin tanpa menyertakan keberimanannya kepada kitab-kitab suci sebelumnya. Untuk umat Islam, ada ketentuan bahwa sekurang-kurangnya ada empat kitab suci yag harus diimani, yaitu Kitab Zabur diturunkan kepada Nabi Dawud, Taurat diturunkan kepada Nabi Musa, dan Injil diturunkan kepada Nabi Isa dan al-Quran diturunkan Nabi Muhammad saw.

Melihat adanya hubungan erat yang tak terpisahkan antara kitab-kitab terdahulu dengan al-Qur'an. Hal itu mengindikasikan bahwa tidak ada alasan untuk bermusuhan dengan saudara-saudara kita yang berbeda Agama (Ahlul Kitab). Karena sekalipun berbeda Agama tetapi sebenarnya sumbernya dari Yang Maha Satu yaitu Allah swt.

Al-Qur'an diturunkan kepada Nabi Muhammad tidak berupa bundelan mushaf yang bisa langsung dibaca. Al-Qur'an tidak hadir sekonyong-konyong menjadi teks dengan lekukan huruf-huruf yang rapih dan tertib. Ada bentangan sejarah yang cukup panjang sehingga al-Qur'an sampai pada kondisinya sekarang. Sehingga perbedaan pemahaman dan penafsiran al-Qur'an sebagai suatu keniscayaan. Yang satu mengatakan; hendaknya dalam memahami teks mesti dilakukan secara harfiah-literalis. Sementara yang lain mendekatinya secara kritis-kontekstualis. Mereka berusaha memahami al-Qur'an berangkat dari teks di samping juga harus mempelajari kondisi sosio-kultural dimana al-Qur'an diturunkan. Karena al-Qur'an turun dalam konteks yang spesifik, peranan ilmu sabab al-nuzul adalah mutlak diperlukan. Semua itu menyebabkan al-Qur'an sebagai kitab suci selalu menarik untuk dikaji dan ditelaah. 


\section{Daftar Pustaka}

'Abdillah, Abu Muhammad Ibn Isma'il al-Bukhari. Al-Jami' al-Sahih Al-Mukhtasar. Baerut: Dar Ibn Kathir, 1987.

'Abed, Muhammad al-Jabiri. Bunyah al-Aql al-'Arabi; Dirasah Tahliliyyah Naqdiyyah li Nuzum al-Ma'rifah li Thaqafah al-Arabiyyah. Baerut: al-Markaz al-Thaqafi al-Arabi.

Al-Banna, .Jamal. Al-Jihad. Kairo: Dar Al-Fikr Al-Islami, 2002.

al-Din, Fakhr al-Razi. Mafatih al-Ghaib. Baerut: Dar al-Fikr, 1993.

Ali, Jawwad. Tarikh al-Salah fi Islam. Baghdad: Matba'ah diya, t.t.

Goldziher, Ignaz. Madhahib al-Tafsir al-Islami. Kairo: Maktabah al-Sunnah al-Muhammadiyah, 1955.

Husain, Muhammad al-Dhahabi. Al-Tafsir wa Al-Mufassirun. Kairo: t.p. 1979.

Huwaidi, Fahmi. Al-Qur'an wa Al-Sultan: Humum Islamiyah Mu'ashirah. Kairo: Dar al-Shuruq, 1998.

Ibn, Ahmad Ali ibn Hajar Al-Atsqalani. Fath Al-Bari bi Syarh Shahih Al-Bukhari. Berut: Dar al-Fikr 2000.

Ibn, Mahmud Umar al-Zamakhshari. Tafsir Al-Kashshaf. Baerut: Dar Al-Kutub Al-'Ilmiyah, 1995.

Ibn, Muhammad Ahmad al-Ansari al-Qurtubi. Al-Jâmi Li Ahkâm Al-Qur'an. Baerut: Dâr Al-Fikr, 1995.

Ishaq, Ibn. Al-Sirah Al-Nabawiyah. Kairo: Qutta al-Thaqafah, 1998.

Khaldun, Ibn. Muqaddimah Ibn Khaldun. Baerut: Dar al-Fikr, t.t.

Manzur, Ibn Muhammad. Lisan al-Arab. Baerut: Dâr Al-Fikr, 1994.

Nawawi, Muhammad al-Jawi. Nihayat al-Zain fi Irshad al-Mubtadi,. Semarang: Thaha Putra, t.t.

Saifuddin, Endang Anshari. Wawasan Islam Pokok-pokok Pikiran tentang Islam dan Ummatnya .Bandung: Pustaka,1983.

Sartono Kartodirdjo, Pemikiran dan Perkembangan Historiografi Indonesia, Suatu Alternatif Jakarta, Gramedia. 1984.

a1-Sabuni, Ali. al-Tibyan fî 'Ulum al-Qur'an. Baerut: 'Alam al-Kutub,t.t.

Shata, Muhammad al-Dimyati. I'anah Talibin. Semarang: Thaha Putra, t.t.

Thabathaba'i, Al-Mizan fi Tafsir al-Qur'an. Beirut: Dar al-Fikr t.t

Al-Zakarshi. Al-Burhan fi Ulum al-Qur'an. Mesir: 'Isa al-Bab al-Halabi, 1972. 